\title{
OLHARES PERCEPTIVOS: USOS E SENTIDOS DA FOTOGRAFIA NA EDUCAÇÃO AMBIENTAL
}

\author{
Lakshmi Juliane Vallim Hofstatter ${ }^{1}$ \\ Haydée Torres de Oliveira ${ }^{2}$
}

Resumo: Apesar de vivermos em uma civilização que cultua fortemente a imagem, e, por consequência, a fotografia, seu uso na educação ambiental ainda é pouco discutido, principalmente, em relação à sua interpretação. Neste trabalho desenvolvemos a perspectiva da inserção fotográfica na educação ambiental crítica. Buscamos, por meio do processo educativo, o desenvolvimento do que denominamos de olhares perceptivos - olhares capazes de compreender fotografias enquanto formas e espaços que constituem o indivíduo. Esta pesquisa qualitativa foi pautada em metodologias participativas e no método de fotoelicitação. A coleta de dados foi realizada durante um processo formativo de professoras/es em uma escola municipal de Barra-BA, localizada em uma comunidade na Caatinga. Analisamos esses dados, assumindo preceitos da semiótica e da hermenêutica interpretativa. Observamos que a fotografia pode desempenhar um papel importante para a educação ambiental crítica, constituindo uma estratégia transdisciplinar, potencialmente sensibilizadora por permitir a expressão de sentidos e significâncias para os seres humanos.

Palavras-chave: Interpretação fotográfica. Formação de professoras/es. Caatinga.

\section{PERCEPTIVE LOOKS: USES AND SENSES OF PHOTOGRAPHY IN ENVIRONMENTAL EDUCATION}

Abstract: In spite of being inserted in a civilization that strongly worships the images, the use of photography in environmental education is still little discussed in relation to the interpretation of images. Our work discusses the photographic insert in critical environmental education. We seek, through the educational process, the perceptive looks development - looks able to produce and understand photographs in a critical perspective as representation of forms and spaces that compose people. This qualitative survey was guided for participatory methodologies and was chosen the method photo - elicitation. Data were collected during a process of teachers' education in a municipal school in Barra-BA, a community located in the Caatinga. We analyzed these data with assumptions of semiotics and hermeneutics interpretation. We observed that photography can play an important role for critical environmental education, constituting a transdisciplinary strategy, which is potentially sensitizer and a expressions of feeling and significance to human beings.

\footnotetext{
${ }^{1}$ Doutoranda no Programa de Pós-Graduação em Ecologia e Recursos Naturais, Universidade Federal de São Carlos, São Carlos, Brasil. lakshmivallim@gmail.com

${ }^{2}$ Doutora em Ciências da Engenharia Ambiental pela Universidade de São Paulo. Professora Titular do Departamento de Ciências Ambientais da Universidade Federal de São Carlos (UFSCar), São Carlos, São Paulo, Brasil.

haydee.ufscar@gmail.com
} 
Keywords: Photographic interpretation. Teachers' education. Caatinga.

\section{MIRADAS PERCEPTIVAS: USOS Y SENTIDOS DE LA FOTOGRAFÍA EN LA EDUCACIÓN AMBIENTAL}

Resumen: Aunque vivimos en una civilización que valora la imagen, y por lo tanto la fotografía, su uso en la educación ambiental es, todavía, poco discutido, principalmente en relación con su interpretación. En este trabajo desarrollamos la perspectiva de la inserción fotográfica en la educación ambiental crítica. Buscamos, a través del proceso educativo, el desarrollo de las miradas perceptivas - una mirada capaz de entender las imágenes como las formas y los espacios que componen el individuo. Esta investigación cualitativa se basa en metodologías participativas y el método de fotoelicitação. La recolección de datos se llevó a cabo durante un proceso de formación de los profesores en una escuela municipal en Barra, Bahia, situada en una comunidad en la Caatinga. Analizamos estos datos, asumiendo los principios de la semiótica y la interpretación hermenéutica. Observamos que la fotografía puede desempeñar un papel importante para la educación ambiental crítica, constituyendo una estrategia transdisciplinaria potencialmente sensibilizante por permitir la expresión de sentidos y significado para los seres humanos.

Palabras-llave: Interpretación fotográfica. Formación de maestros(as). Caatinga.

\section{Introdução}

O uso da fotografia no campo da educação ambiental nos parece um tema fértil para o diálogo, pois a fotografia é um recurso comunicativo e midiático cada vez mais acessível e difundido, em grande parte pela internet e redes sociais.

Recursos fotográficos embutidos em celulares e outros equipamentos, e o fim do custo das revelações facilitam o registro de momentos e acontecimentos cotidianos.

Existe um enorme potencial demonstrativo em fotografias, expresso pelo ditado popular - uma imagem fala mais do que mil palavras. Berger $(1974$, p. 14) contempla a mesma ideia, de forma mais erudita, ao dizer que "as palavras não superam a função do que se pode ver", defendendo, assim, o papel comunicativo das imagens, e inicia seu livro dizendo: "la vista llega antes que las palabras. El niño mira y ve antes de hablar".

As fotografias consolidaram-se em diversas esferas sociais e em praticamente todos os campos de estudo e pesquisa, e são cada vez mais utilizadas para a produção de dados qualitativos. Aliás, o seu uso já tem uma longa tradição na antropologia visual e na etnografia (FLICK, 2009). Entretanto, apesar do acesso à fotografia e aos equipamentos fotográficos ter se difundido, é importante ressaltar que o hábito de fazer, ver e ler fotografia é construído socialmente, ou seja, existe um aprendizado para que isso aconteça, o que inclui um direcionamento bidimensional e plano do olhar para enxergar e entender a fotografia enquanto representação.

Como argumenta Loizos (2010), é falsa a ideia de que a fotografia é universalmente acessível e que opera transculturalmente. Pressupõe-se que as pessoas isoladas da economia global, não acostumadas com fotografias ou espelhos, teriam uma possível dificuldade de reconhecer a si mesmas enquanto imagens. Assim, os contextos sociais influenciam na captação, leitura e percepção da imagem. De forma geral, grande parte da sociedade urbanoindustrial na qual vivemos é ocularcentrista, ou seja, favorece a visão em detrimento de outros sentidos (BANKS, 2009). Vivemos o que Joly (2007, p.9) denomina como "civilização da imagem". Essa civilização da imagem proporciona que as pessoas produzam e divulguem 
suas imagens, de maneira quase imediata, o que se aproxima da democratização da comunicação. Entretanto, também observamos a banalização no uso das imagens, o que implica em um maior cuidado e um grande desafio proceder uma análise de significância ou relevância do que se quer comunicar.

Podemos questionar se, perante a quantidade de imagens, estariam os olhares menos qualificados e analíticos para ler o que esses códigos e signos expressam? Segundo Santaella (2012, p. 76), “o que se ganha em democratização, perde-se em especialização". Portanto, esse é um tema interessante a ser pesquisado e que pode contribuir para o uso de imagens em processos educativos.

Uma educação que se reestrutura, acompanhando as mudanças sociológicas, pode amplificar as formas de comunicação, expressão e linguagens, aproveitando melhor os recursos visuais e educando para uma melhor compreensão de significados. Entre as áreas em que a fotografia tem sido utilizada inclui-se a Educação Ambiental (EA), tema deste artigo.

Entre as diferentes linhas e/ou correntes de educação ambiental, buscamos desenvolver a EA crítica (SORRENTINO, 2002; SAUVÉ, 2005a). Nessa vertente, Carvalho (2008) argumenta que os processos de formação do sujeito humano instituiriam novos modos de ser, de compreender e de posicionar-se ante os outros e a si mesmo, enfrentando os desafios e crises do tempo em que vivemos. Segundo a referida autora, "o projeto político pedagógico de uma EA crítica poderia ser sintetizado na intenção de contribuir para uma mudança de valores e atitudes, formando um sujeito ecológico capaz de identificar e problematizar as questões socioambientais e agir sobre elas" (CARVALHO, 2008, p. 156157). No mesmo sentido, Guimarães (2000, p. 67) sugere que nas práticas de EA "a ação crítica sobre o processo social possibilite a formação de cidadãos comprometidos com a questão da qualidade ambiental".

A escolha da corrente crítica de EA se deve ao entendimento de que para uma análise de sentidos e significados das imagens fotográficas, há que se analisar as relações sociais das quais o sujeito é parte e nas quais ele pode atuar. Propõe-se que, através de práticas dialógicas e participativas, a educação desenvolva valores propagados por Freire (2003), tais como a autonomia, a valorização da pluralidade de culturas e emancipação educacional e política. Também nos aproximamos do que Carvalho e Grun (2005, p. 179) denominam de educação ambiental compreensiva trazendo o entendimento da linguagem enquanto "aplicação, interpretação e compreensão, no encontro do eu com o mundo".

Trabalhamos com uma abordagem transdisciplinar, como forma de superação da lógica cartesiana e da fragmentação dos seres humanos nos aspectos racionais, afetivos e subjetivos, aproximando diferentes campos de conhecimentos e procurando uma axiomática comum entre ciências, arte, filosofia, religião e conhecimentos tradicionais (OLIVEIRA, 2005). Entendemos que a fotografia, enquanto arte e comunicação sobre relação humana com o ambiente e expressão de cultura, oportuniza essa abordagem.

Dessa maneira, abarcando todos esses aspectos descritos, o presente trabalho dedica-se a apresentar algumas formas de inserção da fotografia como meio de análise da percepção ambiental das professoras e dos professores ${ }^{3}$ da rede municipal de Barra, na Bahia, buscando a construção e a ampliação do que denominamos olhares perceptivos.

\section{A comunicação e a interpretação fotográfica na educação ambiental}

Para a EA crítica, a análise do contexto socioambiental é essencial dentro dos processos de formação. Entender o espaço geográfico e a história do lugar é tão importante quanto compreender de qual forma as pessoas que o habitam se relacionam e percebem seu

\footnotetext{
${ }^{3}$ Fazemos opção pelo uso não sexista da linguagem.
} 
ambiente. Diferentes formas de conhecer as percepções ambientais podem ser utilizadas, dependendo da pesquisa, atuação, contexto, pretensão e da habilidade da pesquisadora ou do pesquisador.

Nesta pesquisa, optamos por realizar uma interpretação dos sentidos e percepções ambientais através da fotografia, vislumbrando seu potencial comunicativo. A semiótica foi utilizada enquanto fundamentação teórica para a análise de imagens fotográficas. Essa ciência dos signos, fundada por Charles Peirce, é definida pela pesquisadora Lúcia Santaella como "a ciência que tem por objeto de investigação todas as linguagens possíveis, ou seja, que tem por objetivo o exame dos modos de constituição de todo e qualquer fenômeno de produção de significado e sentido" (SANTAELLA, 2007, p. 13). Como exposto por Pires e Contani (2005, p. 181) "a semiótica peirceana se mostrou um instrumento epistemológico potente no aprofundamento de estudos sobre as relações sígnicas da imagem fotográfica".

Além disso, a semiótica traz alguns elementos interessantes quando pensamos na utilização da fotografia para a EA crítica, pois considera três aspectos importantes. O primeiro, demonstrado por Santaella (2007, p. 10), é a pluralidade comunicativa, que inclui as imagens e considera que "somos uma espécie animal tão complexa quanto são complexas e plurais as linguagens que nos constituem como seres simbólicos, isto é, seres de linguagem". O segundo refere-se à necessidade de interpretar essas linguagens pois, segundo Penn (2010, p. 319), "a semiologia provê o analista com um conjunto de instrumentais conceptuais para uma abordagem sistemática dos sistemas de signos, para descobrir como eles produzem sentido". Para tanto, a semiótica utiliza a fenomenologia para desvelar, nos signos, a percepção dos sujeitos (FERRARA, 1993; JOLY, 2007; SANTAELLA, 2007, 2012; PENN, 2010), aproximando-se, também, da EA interpretativa e compreensiva. O terceiro trata, propriamente, da análise semiótica que propõe uma triangulação entre o significado do interpretante, o representante do significado e o objeto referente, cuja significação depende do contexto de seu aparecimento além da expectativa, repertório e sentidos de seu receptor (JOLY, 2007).

Na fotografia o objeto referente, como define Barthes (1984), não é o mesmo que os outros sistemas de representação, pois expõe o que foi colocado diante da objetiva, sem a qual não haveria a fotografia. Portanto, analisar uma imagem, enquanto signo, exige atrelar o significante (o sujeito que interpreta), o significado (sempre relacionado a um contexto e a forma de compreensão do mundo) e o objeto referente (o real exposto através da fotografia e que retoma as qualidades formais de seu referente: formas, cores, proporções que permitem reconhecê-los). Toda imagem possui o aspecto icônico muito dominante, mas é, obrigatoriamente, um índice por remeter a algo que existe de fato. $\mathrm{O}$ signo comporta-se como símbolo quando possui reconhecimento coletivo (SANTAELLA; NOTH, 2012).

A fotografia, enquanto forma de representação de algo concreto, é um recorte operado por alguém, que também entende esse mundo de maneira particular e que, ao se ausentar, faz com que a imagem emita por si elementos comunicativos. Trata-se de uma "construção interpretativa de um referente cuja ausência promove autonomia a esta" (MICHELON, 2007, p. 189). Ressalva-se, apenas, manipulações mal-intencionadas que podem ocorrer se a pessoa que fotografa não for idônea, portanto, não se deve acreditar puramente em evidências visuais, sem outras formas de investigação (LOIZOS, 2010).

As imagens fotográficas apresentam diferentes formas de uso, dependendo da área em que são utilizadas. Assim, servem ao registro científico, às demonstrações técnicas e fins didáticos. Porém, áreas como a comunicação, a sociologia, a psicologia e as artes buscam os sentidos e significados que decorrem da comunicação fotográfica, sendo essas áreas que, portanto, elaboram discussões sobre a interpretação e a expressão das imagens. Berger (1974, p. 14) afirma que "nunca olhamos só uma coisa, sempre olhamos a relação entre as coisas e nós mesmos". De forma que as explicações ou interpretações acontecem a partir do olhar e 
sentir humanos. Isso porque, como apontam Santaella e Noth (2012), o mundo das imagens tem tanto o domínio da representação visual em si, como é o caso da fotografia, como o domínio imaterial das imagens que formamos em nossa mente, e ambas estão inextricavelmente ligadas.

Na educação, Guido e Bruzzo (2008, p. 52) apontam que "quanto mais significados a imagem transmitir para os diferentes olhares, mais interessante ela é". Na EA crítica as imagens visuais podem ser trabalhadas na esfera educativa, expandindo a leitura das fotografias para as imagens mentais. Para tanto, é preciso educar e construir socialmente sujeitos com olhares perceptivos, cuja sensibilidade e criticidade tragam entendimento do recorte fotográfico relacionado aos cotidianos vividos. Esses sujeitos devem ser capazes de realizar leituras atentas de signos e realidades, construir valores e novos elos cognitivos em um contexto sobre o qual se compreenda e se possa atuar. O desenvolvimento de um olhar mais aguçado deve facilitar a compreensão das relações estabelecidas entre seres humanos com seu mundo em seus aspectos culturais, sociais, políticos, ecológicos e, em sua dinamicidade histórica, multiplicidade interpretativa e de significação e pluralidade epistemológica de tradução e codificação dessas relações.

\section{Usos e sentidos da fotografia na educação ambiental}

O campo de pesquisa em EA ainda é considerado recente, havendo abertura para o desenvolvimento de diferentes métodos que permitam explorar e aprofundar toda a sua pluralidade de atuação. O uso da fotografia nessa área precisa ser melhor discutido e teorizado, enquanto abordagem qualitativa de pesquisa, ensino e prática e constituir, também, um arcabouço teórico consistente. Trabalhos existentes, que fizeram uso da fotografia na educação ambiental, foram unânimes em afirmar a importância dessa arte não somente como forma de expressão, mas, também, de sensibilização das educandas e dos educandos (BORGES; ARANHA; SABINO, 2010); nas representações simbólicas (SILVEIRA; ALVES, 2008); na interpretação de narrativas visuais (FARNSWORTH, 2011); na percepção ambiental do entorno vivido (MORAIS, 2004); no ensino (GUIDO; BRUZZO, 2008); na experimentação e possibilidade inventiva (SALGADO, 2011); no deslocamento do olhar para ver e viver o ambiente (GUIMARÃES; PREVE, 2012).

As imagens possuem o potencial de gerar conhecimentos, ensinar, permitir ler ou conceber mensagens visuais (JOLY, 2007). Elas permitem o desenvolvimento de habilidades para além do espaço formal de ensino, podendo trazer motivação e empenho para o processo educacional. A fotografia é uma experimentação interessante enquanto recurso comunicativo por ser sensível a nuances de cores, texturas e formas que as palavras ou outras formas de comunicação não expressam. Oferece às educandas e aos educandos maneiras mais lúdicas e poéticas de expressão e construção do conhecimento, se comparadas ao ensino tradicional cartesiano.

As educadoras e os educadores ambientais, enquanto pessoas que mediam o processo educacional, independente da forma de trabalho fotográfico, desempenharão o papel de interpretar os sentidos e as percepções do sujeito. Na prática interpretativa, dentro de um repertório de sentidos sociais das relações entre sociedade e natureza, a educadora ou o educador seria um intérprete desses nexos, ou seja, "um intérprete das interpretações socialmente construídas" (CARVALHO; GRUM, 2005, p. 180-181).

No desenvolvimento do processo educacional que objetiva maior autonomia, existe a tendência de que os sujeitos se tornem os próprios intérpretes de seus contextos. Assim, a mediadora ou o mediador pode apresentar, a partir das interpretações postas, diferentes desafios cognitivos e outras reflexões, além de auxiliar na mediação de conflitos 
socioambientais ou contribuir na construção, junto às pessoas, de outras formas de se relacionar com o meio ambiente.

Ferrara (1993, p. 153) afirma que a percepção ambiental deve gerar conhecimento a partir da informação retida, rompendo a opacidade que impede a decodificação de determinados lugares, afirmando, também, que os "usos e hábitos são signos do lugar informado que só se revela na medida em que é submetido a uma operação que expõe a lógica de sua linguagem. A essa operação dá-se o nome de percepção ambiental". De acordo com a autora, é necessário usar a informação gerada para que se façam visíveis aspectos culturais imersos nos cotidianos, desvelando o que se tornou invisível por excesso de visibilidade, pressuposto que também é assumido por Penn (2010). Assim, a EA pode colaborar com esse processo de decodificação e interpretação de sentidos e significados, atuando junto aos sujeitos para que se possa construir e revelar conhecimentos a partir de suas percepções ambientais.

A percepção ambiental envolve o organismo e o ambiente, e é influenciada tanto pelos órgãos dos sentidos - percepção como sensação - como por elaborações mentais oriundas de experiências individuais, associações conceituais e contextos socioculturais - percepção como cognição (HOEFFEL; FADINI, 2007). Dessa forma, a sensação captada pelos sentidos tende a ser racionalizada, ao mesmo tempo em que a elaboração mental também atua na forma como ativamos as sensações, sendo esses aspectos indissociáveis. Porém, devido às diferentes constituições humanas, culturais e psicossociais, os aspectos sensitivos ou cognitivos podem ser mais ou menos ativados.

Discutindo meio ambiente, Sauvé (2005b, p. 317) apresenta as diferentes formas de percebê-lo e apreendê-lo, trazendo o entendimento de que "a trama do meio ambiente é a trama da própria vida, ali onde se encontram natureza e cultura; o meio ambiente é o cadinho em que se forjam nossa identidade, nossas relações com os outros, nosso ser-no-mundo". Essa definição delimita aspectos importantes para o entendimento sobre a percepção ambiental dos seres humanos, pois a expressão sensorial e seus processos cognitivos ocorrem de acordo com suas experiências de vida e pela forma com que se relacionam com seus meios. Além disso, o ambiente percebido existe em um tempo e espaço delimitados por relações e processos culturais.

Seguindo na mesma linha de raciocínio, que diferencia as sensações imediatas das elaborações cognitivas e a racionalização da experiência sensória, Ferrara (1993), ao expor sobre as duas vertentes de percepção elaboradas por Pierce, - o percepto e o juízo perceptivo - argumenta que o percepto é um registro espontâneo do preceptor, um ato quase automático ao primeiro contato da materialidade exposta que não corresponde a uma crença ou descrença. Enquanto que, o juízo perceptivo depende da consciência do receptor, pois é uma percepção que opera ativamente sobre o percepto e envolve a memória de experiências passadas, gera associações e, portanto, não é um registro pontual, mas um processo.

Essas diferentes compreensões nos permitiram observar, mais atentamente, as motivações do grupo participante na tomada de fotografias durante o trabalho realizado.

\section{Desenvolvimento da Pesquisa}

\subsection{Localização da comunidade}

A comunidade do Brejo dos Olhos d'Água se localiza no município de Barra, ao oeste do estado da Bahia, na região do Baixo-Médio São Francisco, na Área de Proteção Ambiental (APA) Dunas e Veredas do médio-baixo São Francisco. Segundo o censo IBGE de 2010, Barra possui 49.325 habitantes e 54,5\% vivem na zona rural. Entre as pessoas que vivem na zona rural, 16 mil estão na região de Brejos da Barra, onde se localiza essa comunidade 
(IBGE, 2002 apud SOUSA SOBRINHO, 2006). Segundo o referido autor "nas estreitas planícies das vazantes que margeiam os cursos d’água e lagoas estão instaladas as comunidades brejeiras, que praticam nessas áreas culturas de subsistência, e criatórios soltos nas extensas áreas de caatinga" (p.169-170). Drumond et al. (2004) afirmam que, na Caatinga, grande parte da população é carente de recursos financeiros e faz uso direto dos recursos naturais para sua sobrevivência, por vezes, sem o devido planejamento, o que também se observou na comunidade trabalhada.

\subsection{Grupo participante e coleta de dados}

O processo educativo proposto teve o formato de um curso de formação com professoras e professores, um grupo que consideramos influente nessa comunidade, pela responsabilidade formal que possuem na educação das crianças. A turma foi formada por 25 pessoas: 19 professoras ou professores e 6 integrantes da comunidade, que tiveram interesse em participar. Houve uma média de 20 participantes nos quatro encontros, realizados entre setembro de 2012 e março de 2013. Utilizamos metodologias participativas para uma construção colaborativa do conhecimento em todo o processo. Os dados foram coletados por meio de observações em campo e de questionário. As discussões, a partir das atividades propostas, foram gravadas com o consentimento verbal do grupo, após esclarecimento sobre o objetivo da pesquisa e comprometimento na devolução de resultados.

\subsection{Caminho metodológico}

Esta pesquisa foi pautada em metodologias qualitativas para coleta e análise de dados. Percorreu o viés interpretativo, no qual os dados não existem de forma independente, por isso necessita do envolvimento do grupo participantes para realizar interpretações com as quais se identificam (BANKS, 2009). Os dados foram produzidos conjuntamente com os sujeitos e a primeira pesquisadora. Utilizamos preceitos da semiótica para analisar e interpretar os signos presentes nas imagens fotográficas (FERRARA, 1993; TACCA, 2005; JOLY, 2007; SANTAELLA, 2007; PENN, 2010) e a hermenêutica no ato de interpretar o subjetivo durante o processo conhecedor e de revelar o que está implícito no explícito (HERMANN, 2002; FLICK, 2009, PENN, 2010).

A interpretação, fundamental para a análise de dados visuais, ocorre em função do que se denomina de polivocalidade das imagens, que é a capacidade de permitir múltiplas leituras influenciadas pelo contexto dos intérpretes (BANKS, 2009). Porém, apesar de todo potencial comunicativo que as imagens apresentam, uma perspectiva que defendemos, não poderíamos deixar de observar a limitação da pesquisa com dados visuais em que a interpretação de imagens ainda recorre a recursos da interpretação textual e dos dados verbais, ou seja, não há uma forma genuína de análise das imagens por si próprias (BANKS, 2009; FLICK, 2009).

Santaella e Noth (2012, p. 55) esclarecem que: "a relação entre a imagem e seu contexto verbal é íntima e variada. A imagem pode ilustrar um texto verbal ou o texto pode esclarecer a imagem na forma de um comentário". Assim, para a autora e o autor, essa relação pode cumprir diferentes papéis: a) dominância da imagem em relação à fala, a imagem é superior ao texto, traz mais informação; b) redundância da informação, texto e imagem dizem a mesma coisa; c) complementaridade de informação, texto e imagem se complementam e d) discrepância, quando há contradição entre o expresso pela palavra e aquele pela imagem. Com base nesses pressupostos é que assumimos a análise dos dados visuais a partir da descrição 
feita pelas autoras e pelos autores das fotografias, registrando suas intencionalidades e percepções como eixo da pesquisa.

No primeiro encontro com a turma, houve a aplicação de um questionário com algumas perguntas focadas em questões ambientais, além de duas questões específicas sobre uso da fotografia para fins didáticos e sobre percepção ambiental, as quais são apresentadas neste artigo. $\mathrm{Na}$ apresentação das respostas, optamos por manter a forma de redação, alterando apenas o que pudesse comprometer o entendimento da argumentação. Também optamos em não personificar as pessoas, pois nosso interesse de análise dos dados não teve foco individual. Antes da realização da saída fotográfica, outros métodos participativos foram utilizados para fazer emergir a percepção do espaço de vida desses sujeitos (HOFSTATTER, 2013). Também foi feita uma aula expositivo-dialogada, introduzindo questões sobre técnicas fotográficas, enfocando que, no caso, um breve conhecimento desses assuntos poderia auxiliar no uso da fotografia enquanto meio de comunicação.

Esse tipo de trabalho fotográfico pode desenvolver a aproximação e o contato com a natureza, fazendo com que vivenciem e desloquem o olhar para experimentarem a comunidade de forma diferente das cotidianas (FARNSWORTH, 2011; GUIMARÃES; PREVE, 2012). Dessa forma, para a produção de imagens em campo as pessoas se reuniram livremente em quatro grupos e saíram pelo espaço ao redor da escola e pela comunidade de Brejo dos Olhos d'Água para fotografarem aspectos socioambientais que considerassem importantes na localidade.

Além disso, a produção de imagens permitiu a experimentação e familiarização com a fotografia enquanto forma de representação e comunicação. Nessa turma específica, formada por maioria de professoras e professores, existia a possibilidade de aprenderem a fotografia para utilizá-la como recurso didático em suas atuações profissionais, se assim o desejassem. Guido e Bruzzo (2008) destacam que é muito importante que a pessoa que ensina esteja preparada para analisar os meios de comunicação e discuti-los com quem aprende, e a interpretação de imagens pode auxiliar nessa atividade.

Depois da saída, voltamos à escola e cada grupo apresentou suas imagens. O método escolhido é denominado de fotoelicitação, no qual as fotografias são utilizadas para gerar discussões, evocar memórias e comentários (BANKS, 2009). De modo geral, as fotografias têm uma alta qualidade icônica, podendo ativar memórias e auxiliar na elaboração de enunciados sobre situações e processos complexos (FLICK, 2009). Foi, então, solicitado que compartilhassem o que pretendiam mostrar através das imagens e o que era significativo nas mesmas. A atividade foi conduzida e direcionada, em alguns momentos, pela pesquisadora, quando era percebida a importância do assunto para a turma. A apresentação foi gravada em áudio, o que permitiu uma verificação posterior dos comentários gerados, bem como a excitação do grupo perante algumas temáticas.

Ressaltamos o compromisso que se deve ter com as pessoas envolvidas e a ética com as pessoas fotografadas (SOUTO, 2010). Na pesquisa em EA existe uma dimensão maior do que a produção de dados, que é a do retorno educacional.

\section{Dialogando com os Resultados}

Do total de 25 participantes, 14 responderam ao questionário referido no item da coleta de dados. Na primeira pergunta relativa à prática fotográfica: você acha que a fotografia pode ser usada como recurso didático de ensino? Exemplifique como; obtivemos totalidade de respostas positivas, ou seja, todos consideram que a fotografia pode ser utilizada como recurso didático. A segunda questão: você acha que a fotografia pode ser usada como forma de conhecimento de aspectos ambientais do local onde você vive? Justifique; absolutamente todas as respostas também afirmam que sim. 
Considerando-se a realidade dessas pessoas, que vivem na sede da cidade, na própria comunidade ou em comunidades vizinhas, afastadas de grandes centros urbanos, onde o apelo no uso de imagens para fins comerciais é muito forte e constante, os tipos de argumentos trazidos merecem destaque. A compreensão que já traziam sobre o uso de imagens fotográficas é ampla, mesmo que nunca tivessem refletido sobre isso ou utilizado a fotografia enquanto recurso didático, como relataram oralmente.

A prática fotográfica proporcionou uma maior participação e envolvimento da turma, além de revelar aspectos de vidas e de interações com o ambiente que não estariam disponíveis de outra forma. O reconhecimento das diversas vocações no uso das fotografias é algo que aparece no conjunto das respostas.

Podemos observar o potencial das imagens, como modo conhecedor da cultura e modos de vida, demonstrado na fala: "a fotografia mostra o modo de sobrevivência das pessoas, o modo de trabalho, cultura e religião". O potencial comunicativo é expresso em: "várias linguagens diante de um contexto" e, também, em: "a imagem fala através de significado". Outras respostas apontam o importante papel do receptor (no caso, as alunas e os alunos e as moradoras e moradores) e do processo educativo crítico, observado nas seguintes colocações: "os alunos poderão fazer uma análise crítica sobre o que cada item quer dizer para a pessoa" e "pode-se mostrar a um morador uma foto antiga em estado conservado e outra como está hoje, sem dúvida ele repensará seus conceitos".

A resposta "nós conhecemos o local onde vivemos, mas por outro lado serve para mostrar para aqueles que nunca tiveram acesso à visualização do meio ambiente", demonstra que as fotografias podem colaborar no entendimento e conhecimento do ambiente e que a imagem pode ir até as pessoas que desconhecem aquela realidade, ou seja, pode ser usada em lugares distantes desse ambiente vivido para que os outros o visualizem. $\mathrm{O}$ uso de imagem para aguçar os olhares é expresso em "podem ser focados locais da comunidade que as pessoas não tenham prestado atenção". Destaca-se, ainda, a importância de ilustrar e concretizar com imagens o que se explica ou se ensina, como afirmado por um participante: "aquilo que é palpável torna possível assimilar melhor aquilo que é passado".

Como demonstrado nessas respostas, os conhecimentos ou intuições sobre o tema e as justificativas apresentadas confirmam que a fotografia é uma forma de trabalho realmente muito enriquecedora, dentro ou fora da sala de aula. Muitos dos argumentos se aproximam das referências teóricas utilizadas nesta pesquisa; por exemplo, o uso da fotografia enquanto registro da passagem do tempo, de processos culturais em transformação e de mudanças históricas no uso e ocupação dos espaços, defendido por Loizos (2010). Os argumentos também selam aproximações teóricas referente à polivocalidade das imagens (BANKS, 2009) e, em relação a própria semiótica (SANTAELLA, 2007, 2012; FERRARA, 1993), pois evidencia-se a percepção de uma triangulação entre sujeito, que ao realizar uma leitura crítica do meio, relaciona-se com seu contexto e objeto.

Não limitamos a quantidade de fotos produzidas pela turma, que foram entregues em meio digital. Analisamos as imagens, observando o que retratavam e correlacionando com o contexto, com outras atividades do curso e apoiadas nas falas das pessoas. Conforme descrito por Santaella (2012), o dispositivo fotográfico funcionou como uma "extensão mecânica do olho", ou seja, uma forma de as pessoas mostrarem umas às outras a apreensão de seus olhares, em um espaço e tempo, no registro de imagens. É importante destacar, ainda, que cada uma das fotos representa um recorte espacial e, sendo assim, podemos considerar que os sujeitos já iniciaram uma interpretação ambiental durante o ato fotográfico. A escolha do registro opera dentro do repertório de signos que representa aquele universo e remete aos seus modos de vida, uma vez que foram solicitadas fotografias sobre elementos socioambientais importantes. A interpretação fotográfica iniciou-se pela observação das imagens, captando suas características fenomenológicas. O quadro 1 apresenta a sistematização das temáticas: 
Quadro 1 - Temáticas presentes nas fotografias realizadas em campo

\begin{tabular}{|c|c|c|c|c|}
\hline Temática & $\begin{array}{l}\text { Grupo } \\
1\end{array}$ & $\begin{array}{l}\text { Grupo } \\
2\end{array}$ & $\begin{array}{l}\text { Grupo } \\
\mathbf{3}\end{array}$ & $\begin{array}{l}\text { Grupo } \\
4\end{array}$ \\
\hline $\begin{array}{l}\text { 1. Aspectos relacionados à água ou a seca, } \\
\text { (incluindo gado magro e peixe) }\end{array}$ & $11^{*}$ & 4 & 6 & 3 \\
\hline $\begin{array}{l}\text { 2. Engenho de produção de rapadura ou } \\
\text { plantação de cana }\end{array}$ & $12 * *$ & 2 & - & 3 \\
\hline 3. Buriti (cultura nativa mais abundante) & 1 & - & 3 & 4 \\
\hline $\begin{array}{l}\text { 4. Buriti + Cana (representando os aspectos } \\
\text { econômicos que mais se destacam na } \\
\text { comunidade) }\end{array}$ & - & 1 & 2 & 1 \\
\hline 5. Outras culturas (Mandioca, Manga, Caju) & 1 & 1 & - & \\
\hline $\begin{array}{l}\text { 6. Pessoas da comunidade (sem serem os } \\
\text { participantes) integradas à paisagem }\end{array}$ & $2 * * *$ & - & $4 * * *$ & 1 \\
\hline $\begin{array}{l}\text { 7. Somente pessoas da comunidade } \\
\text { mostrar paisagem) }\end{array}$ & - & 2 & - & - \\
\hline 8. Carroça (usada no trabalho local) & - & 1 & - & - \\
\hline Total do número de fotos & 25 & 11 & 11 & 12 \\
\hline \multicolumn{5}{|c|}{$\begin{array}{l}* 4 \text { dessas fotos tem algum membro do grupo presente na imagem } \\
* * 3 \text { dessas fotos tem algum membro do grupo presente na imagem } \\
* * * \text { Essas fotos estão incluídas no item } 1 \mathrm{e} \text {, portanto, não foram contabilizadas }\end{array}$} \\
\hline
\end{tabular}

Fonte: as autoras

Quando uma análise é feita semioticamente, assume-se a posição de interpretante, uma condição que é falível. Portanto, deve-se ter o cuidado de observar a lógica interna das relações do signo e acompanhar o percurso dos interpretantes (PIRES; CONTANI, 2005). A temática 1, que retrata a água, foi a temática mais presente nos quatro grupos. Na sequência, aparecem outras temáticas, presentes em três grupos e assim sucessivamente. Todas as fotografias foram apresentadas pelos grupos, que justificaram seus motivos de escolha. Foi possível, pelas apresentações, subdividir as temáticas em três grandes categorias de importância local: a água; os modos de vida relacionados aos recursos naturais e as pessoas da comunidade.

Não é por acaso que a água foi a temática mais presente em todos os grupos, pois a água é, de fato, um elemento muito forte na relação entre os seres humanos com o meio ambiente (MARIN; OLIVEIRA; COMAR, 2003); no sertão, para quem vive a sua ausência, a relação é ainda mais forte. Nessa primeira categoria estabelecida, as fotografias n.1 (grupo 1) e n.4 (grupo 4) retratam a água diretamente, em uma forma comum de se encontrá-la na comunidade, que são brejos e as pequenas poças, o que explica o fato de a comunidade chamar-se Brejo dos Olhos d'Água.

As outras duas fotografias representam a água, através do gado e do peixe. A fotografia n.2 (grupo 2), mostrando o gado magro reflete a questão da seca. Semioticamente, a imagem ultrapassa o signo enquanto índice, pois representa mais do que o gado que existe na comunidade, podendo-se dizer que é um signo que representa a seca no Nordeste. Assim, remete a uma imagem mental presente no imaginário social, difundida pela mídia e, que opera enquanto símbolo, por se tratar de um signo expressivo de amplo reconhecimento coletivo (Figura 1). 
Figura 1 - Fotografias n.1; n.2; n.3; n.4: representações da água

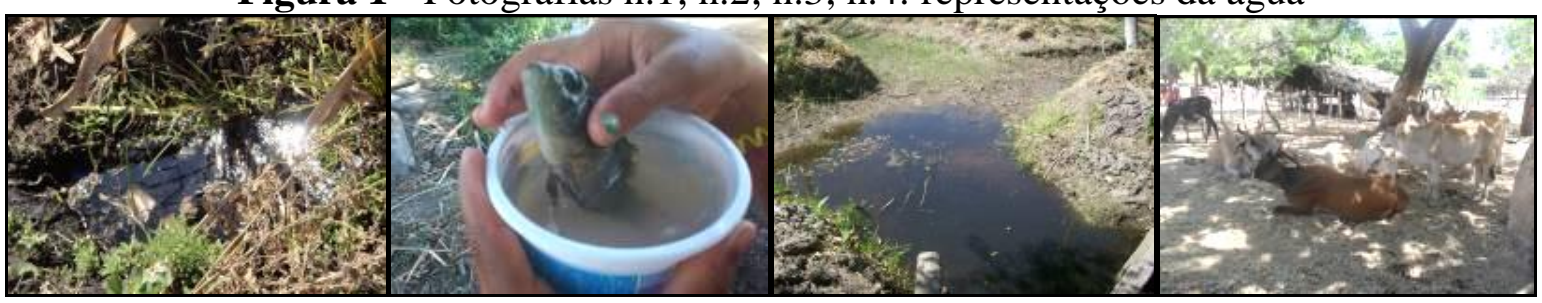

Fonte: imagens captadas pela turma participante da pesquisa

A fotografia do peixe (grupo 3) enquanto signo, certamente, remete à água, mas dificilmente à seca, como é o caso do gado magro. Porém, quando o grupo apresentou a fotografia, as falas foram primeiramente sobre a água, mas logo convergiram ao esgotamento da água e à seca dos riachos. Essa é uma associação que não é nítida pela imagem, apenas pelas expressões verbais. Assim, nas funções descritas por Santaella (2012), entre expressão verbal e imagem, são informações complementares.

Na segunda categoria estabelecida, dos modos de vida, destaca-se o buriti e a cana. Segundo as falas das pessoas participantes, nenhuma foto foi feita, exclusivamente, por motivo estético relacionado à beleza cênica, apesar da beleza estar evidente nas fotografias 5 (grupo 3), 6 e 7 (grupo 4) e em outras apresentadas (Figura 2). O fator que mais se destacou nas argumentações foi o fato de o buriti ter alto valor comercial no Brasil e até no exterior, o que é motivo de orgulho para a comunidade. Em relação ao nexo entre argumentação verbal e imagem, nesse caso, se observa uma possível discrepância, pois nas falas espontâneas se evidenciou o valor utilitarista, ao mesmo tempo em que as imagens, por si, trazem um enorme apelo à beleza estética.

Figura 2 - Fotografias n.5; n.6; n.7: Buritis

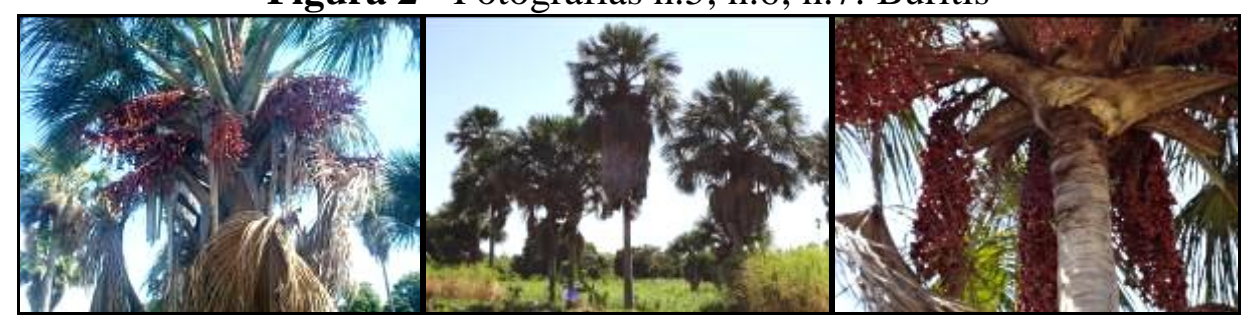

Fonte: imagens captadas pela turma participante da pesquisa

Quando questionados sobre a beleza dessas fotografias as autoras e os autores disseram reconhecer o belo. Porém, a racionalização demonstrada nas falas, e em todo trabalho realizado anteriormente, indicou que a manutenção dos seus modos de vida ocupa o lugar central de suas preocupações, colocando o belo como um plano secundário diante do valor econômico do buriti.

Assim, a elaboração mental acerca de aspectos socioambientais relevantes demonstra que existe a tendência da percepção, enquanto cognição, superar a sensação imediata do contato com a natureza (HOEFFEL; FADINI, 2007), o que pode ser denominado de juízo perceptivo como explicita Ferrara (2003). Os sujeitos revelaram, por meio de argumentos, suas crenças e valores demonstrando, assim, a superação da experiência sensória imediata diante do exposto na materialidade do ato fotográfico.

No nosso entendimento, essa priorização racional e elaboração cognitiva são compreensíveis diante das dificuldades que enfrentam em suas vidas. Porém, investir na sensibilização e valorização da beleza estética local pode gerar sentimentos ainda mais 
profundos de ligação com a natureza, para além dos recursistas. Como expressa Santaella (2012, p. 81) "quanto mais estiver enfatizado o caráter estético de uma fotografia, fruto do talento com que alguns agentes entram em simbiose com o olho da câmera no confronto com o real, mais a foto acionará as faculdades sensíveis dos seus leitores".

Em relação à cana, que é utilizada, principalmente, para a produção de rapadura, a comunidade considera que produz a mais saborosa de toda a região. É um aspecto cultural muito presente, confirmado pelas muitas fotos sobre o tema. Esses signos em torno da cana, desde o plantio até os engenhos de produção da rapadura, representam o que a turma identifica entre os aspectos mais relevantes da cultura local. Como enfatiza Santaella (2012, p. 81) "quanto mais uma foto for portadora de valores simbólicos, mais carregada estará de significados coletivos que falam à cultura" (Figura 3 ).

Figura 3 - Fotografias n.8. Plantio de cana; n.9; n.10: engenho de rapadura

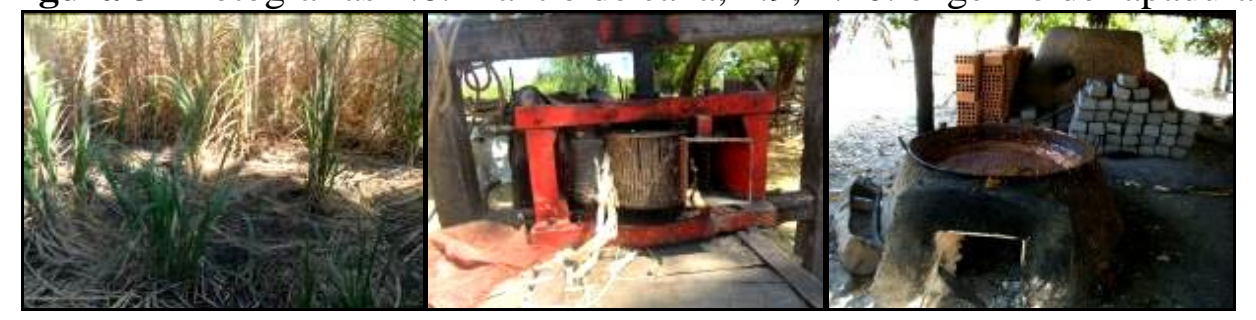

Fonte: imagens captadas pela turma participante da pesquisa

Outros cultivos importantes também foram relatados verbalmente, como a mandioca, que é processada em casas de farinha existentes na comunidade; entretanto, não foram fotografadas. Operou-se a escolha ou uma priorização pela cultura da cana-de-açúcar em relação aos demais plantios, o que aponta a maior relevância dessa cultura, confirmada pelas falas e quantidade de fotos sobre a temática. Ao mesmo tempo, retoma a ideia de que a fotografia é um recorte visual de um todo, e que vão existir elementos importantes não retratados (MICHELON, 2007; BANKS, 2009).

Segundo Tacca (2005, p. 11-12) "por intermédio dessas imagens representativas podemos aproximar a representação imagética da noção de mundo de determinada cultura, por conter valores inerentes nos aspectos de sua produção e de sua consequente significação". A representação imagética, influenciada pela cultura, também pode ser demonstrada pela hermenêutica, pois conforme Hermann (2003, p. 17) "o conhecimento apresenta-se como representação decorrente da atividade do sujeito, o que abre infinitas possibilidades de se referir ao objeto". Assim, é possível compreender o fato de a maioria das fotos refletirem, de diferentes formas, os aspectos vividos culturalmente, como se observa nas fotos n.8 e n.9 (grupo 2) e n.10 (grupo 1).

$\mathrm{Na}$ terceira categoria estabelecida, as pessoas da comunidade, nos leva a deduzir que existe a percepção dos seres humanos integrados na paisagem, considerando que foram muitas as fotos que apresentaram essa integração. Em algumas fotos, alguma pessoa do grupo foi inserida para destacar o que queriam demonstrar, apontando, por exemplo, a manga, o tacho do engenho, o riacho seco. Essa percepção não é um fator que apareça, explicitamente, nas falas. Porém, a análise das imagens permite essa inferência tanto pela frequência de aparição das pessoas relacionadas ao meio, como pelo fato de que, mesmo nas fotos em que não havia nenhum ser humano presente, o elemento retratado era relacional aos modos de vida. $\mathrm{Na}$ relação entre texto verbal e imagem trata-se de dominância, pois a imagem trouxe informações não verbalizadas.

Entre todas as imagens apresentadas por toda a turma, destacamos a fotografia n.7 (grupo 1), descrita pelo grupo que a fez como a mais representativa da realidade local, por 
conter os buritis e a cana, representando os hábitos culturais e comerciais da comunidade. $\mathrm{O}$ grupo foi questionado sobre o que representaria a mulher ali presente. As pessoas integrantes responderam "nosso povo sofrido" e "o povo nordestino" (Figura 4).

Figura 4 - Fotografias n.7: Buriti, cana e dona do terreno; n.8: Riacho seco

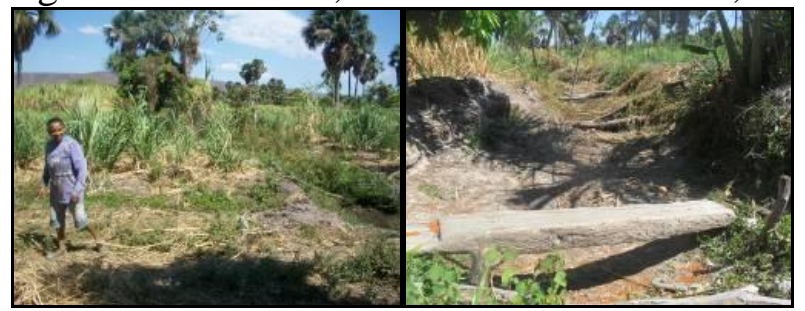

Fonte: imagens captadas pela turma participante da pesquisa

Quando a turma foi solicitada a descrever o porquê desse sofrimento, as pessoas afirmam ser pelo fato de a mulher trabalhar na roça e precisar controlar a irrigação para não perder tudo. Ao estender a discussão para toda a turma, e questionados se era possível afirmar que a referida imagem representava o povo nordestino, as respostas foram todas afirmativas. Houve as seguintes justificativas: "ela planta, faz rapadura, borda" $e$ "aí tá a imagem. Aí é a característica do nordestino, do sofredor". Analisando esse dado, e procurando interpretar seus sentidos, percebemos que o nordestino sofredor pode remeter ao eu sofredor, na leitura do mundo a partir das experiências particulares, como afirmado por Berger (1974). Dada a importância da temática, o assunto foi discutido durante um maior tempo com toda a turma.

A fotografia dessa senhora, escolhida como a mais representativa pela turma, quando analisada pela semiótica, também, se reporta a um símbolo, pois existe uma imagem mental coletiva do nordestino sofredor que trabalha na roça, que tem a vida dura, escassa, e é vítima da seca. Essa concepção também é muito imposta e difundida pela mídia, pelos materiais didáticos e literatura, pois se a vida na roça por si já é um aspecto estereotipado e desvalorizado, frente ao avanço da vida urbana, a imagem difundida sobre a roça e povo nordestino é ainda mais marcante.

Estendeu-se a discussão em relação aos aspectos da seca e sobre a percepção da turma em relação à influência antrópica nos processos que levam à escassez da água, como demonstrado na fotografia n.8 (grupo 2). A turma considera que foi no período dos últimos dez anos que houve o agravamento da seca, atingindo muitos riachos locais, e aponta como motivo o cultivo da cana, que faz uso direto de queimadas, além do desmatamento, o que atribuem aos hábitos dos produtores locais herdados dos seus antepassados. Assim, ao mesmo tempo em que a condição de sofrimento pode justificar a utilização irracional dos recursos naturais para a sobrevivência, existe o entendimento sobre as influências humanas no agravamento das adversidades ambientais.

Retomando o que Ferrara (1993) descreve sobre a percepção enquanto informação, ao discuti-la, busca-se a compreensão sobre o que foi percebido. Segundo Hermann (2002, p. 62) "quando a compreensão se converte em linguagem, realiza-se a consciência histórica". É, então, a partir dessa tomada de consciência que podemos iniciar uma nova etapa da EA relacionada às práticas educacionais dialógicas para abordar conflitos e pensar em possíveis soluções, individuais e coletivas, para uma convivência respeitosa e sustentável com o meio ambiente.

Ao fim das apresentações fotográficas de todos os grupos, foi feita uma discussão geral sobre a atividade, com perguntas direcionadas e transcritas no quadro n.2, o que permitiu um retorno do que a prática trouxe enquanto formação. Foi possível perceber, através das respostas sobre a prática fotográfica, a reafirmação do que as professoras e os professores 
responderam no questionário inicial, que a fotografia pode ser um bom método didático e usada para conhecer o ambiente vivido.

Quadro 2- Discussão sobre o exercício fotográfico

\begin{tabular}{|l|l|}
\hline Perguntas & Respostas \\
\hline $\begin{array}{l}\text { A fotografia foi útil para } \\
\text { conhecer o ambiente? }\end{array}$ & $\begin{array}{l}\text { A fotografia serviu para aprofundar o conhecimento. } \\
\text { É mais fácil de ver do que alguém explicar. } \\
\text { Demonstrar através da imagem é mais real. } \\
\text { É mais fácil de compreender. }\end{array}$ \\
\hline $\begin{array}{l}\text { Vocês usam esse recurso } \\
\text { em sala de aula? }\end{array}$ & $\begin{array}{l}\text { Sim, mas é mais filmes, DVD. } \\
\text { É possível fazer leitura de imagem, igual esse exercício que } \\
\text { a gente fez aqui. Os livros didáticos fazem leitura de } \\
\text { imagem. }\end{array}$ \\
\hline $\begin{array}{l}\text { Vocês acham que a a } \\
\text { imagens dos livros são } \\
\text { boas? }\end{array}$ & $\begin{array}{l}\text { O problema é que não mostra nossa realidade. } \\
\text { Os meninos didáticos a nossa realidade não é representada. }\end{array}$ \\
\hline
\end{tabular}

Fonte: as autoras

Podemos destacar, entre as respostas dadas, o fato de as fotografias e imagens usadas nos livros didáticos não representarem a realidade local e não gerarem uma identificação visual das pessoas e do ambiente. Não foi nosso objetivo analisar a qualidade dos livros didáticos utilizados nas escolas da região, mas a contribuição do uso da fotografia oportuniza, certamente, enriquecer a prática docente em relação a essa questão. As educadoras e os educadores ao fazer suas próprias fotografias, podem ilustrar, com propriedade, o que querem discutir em suas realidades. Na medida do possível, e do acesso aos equipamentos, podem também solicitar que os estudantes façam o mesmo, criando formas de facilitar a apresentação da identidade local. Além disso, contribuem para o que delimita Freire (2003, p. 22): "saber ensinar não é transferir conhecimento, mas criar as possibilidades para a sua própria produção ou a sua construção".

Barthes (1984, p. 121), ao revelar a poesia da relação dos seres humanos com a fotografia, que percorre o imaginário e as emoções, enfatiza seu potencial transformador. $\mathrm{O}$ autor expressa que "a foto do ser desaparecido vem me tocar como os raios retardados de uma estrela. Uma espécie de vínculo umbilical liga a meu olhar o corpo da coisa fotografada”.

Outro fator, observado na prática realizada, foi a potência do diálogo gerado a partir da apresentação das fotos. Como descrito pelo método de fotoelicitação (BANKS, 2009; FLICK, 2009; LOIZOS, 2010), diversos assuntos emergiram com essa prática. Pessoas tímidas, que não se manifestaram em outros momentos, teceram comentários ou dividiram experiências a partir da realidade deflagrada na imagem. Apesar de as discussões terem sido necessárias para suscitar a emergência das percepções e intencionalidades colocadas na tomada das fotos, houve fotografias que revelaram aspectos que não se mostraram verbalmente, como a questão da integração das pessoas à paisagem e a beleza dos buritis.

A temática da água, por outro lado, foi retratada de diferentes formas perceptivas, o que poderia não aparecer oralmente ou exigiria um trabalho mais extenso para que se evidenciasse. Como descrito por Merleau-Ponty (1999) é a partir de experimentações, vivências, percepções e interpretações do eu no mundo que o corpo sinaliza uma percepção do exterior e promove determinada linguagem como resposta. Sob o aspecto fenomenológico, a experiência da seca e a escassez de alguns recursos naturais são os aspectos corporais sentidos e, mais fortemente percebidos, retratados enquanto respostas fotográficas aos modos vividos. 
Segundo Carvalho e Grun (2005) o entendimento desses significados ocorre através da hermenêutica, o que leva à produção de sentidos através da dialogicidade e da interpretação.

\section{Considerações Finais}

Nesta pesquisa pudemos perceber o potencial da prática fotográfica como forma de conhecer e pensar o meio em que vive aquele grupo. Berger (1974, p.14) expressa que "só vemos aquilo que olhamos e olhar é um ato voluntário e como resultado, só vemos aquilo que está em nosso alcance". No cotidiano, quantos elementos existem em nossos caminhos que nossa vista não vê? Podemos descobrir, através de fotos, aspectos para os quais não havíamos direcionado o olhar antes, mesmo que estivesse sempre em nosso campo de visão.

Enquanto instrumento de pesquisa com pessoas, a fotografia também se mostrou um eficiente desencadeador de memórias e discussões (LOIZOS, 2010). O trabalho de Iared, Di Tullio e Oliveira (2012) também demonstrou que as fotografias contribuíram no sentido de subsidiar a lembrança de acontecimentos na prática ambiental educativa. Como exposto por Ferrara (1993) a informação pode ser usada para novos aprendizados e novas reflexões para que as pessoas possam inferir $d a$ e sobre a realidade.

Entre os trabalhos que investigam o uso da fotografia na educação ambiental, há poucos que discutem a fotografia pelo viés interpretativo. A hermenêutica é utilizada, em geral, para processos dialógicos verbais, como em Sammel (2003) e Carvalho e Grun (2005). Isso faz com que seja desafiador constituir formas de aproximação da interpretação no uso de imagens para a EA crítica.

A experimentação transdisciplinar, para que as fronteiras disciplinares diminuam e a educação se torne mais lúdica e diversa, exige que profissionais da educação se proponham a romper com as formas tradicionais de educar, pautadas em estruturas cartesianas. Aproximar as ciências sociais, físicas e biológicas à estética e às artes, agregando informações de qualidade, é uma possibilidade muito valiosa para a educação que percebe o sujeito como múltiplo em habilidades e singular na forma de se expressar e construir seu pensamento. Necessitamos valorizar e aproximar a emoção com as áreas técnicas para formarmos sujeitos com olhares perceptivos, mais sensíveis, humanos e plenos na realização de seus desejos, potenciais artísticos, comunicativos e em relações mais próximas e respeitosas com a natureza.

$\mathrm{Na}$ junção complexa de elementos e linguagens que constituem o ser, os saberes e processos educacionais devem estar atentos às necessidades das pessoas de mais vivência e experimentação, o que pode ser trabalhado através da arte e da fotografia, o que amplifica o sensível e as possibilidades expressivas humanas. Como demonstrado nesta pesquisa, a fotografia compõe um elo entre a realidade concreta e o artístico, entre um recorte espacial com o todo que se relaciona, entre o encontro do olhar externo com o interno e entre os diferentes campos de saber. Possui diferentes formas de uso, tanto na pesquisa como na prática em educação ambiental.

A crítica ao modelo de vida que experimentamos socialmente deve servir de força motriz para a reflexão sobre o que se quer construir, percebendo qual é a imagem, simbólica e física, que temos hoje, e qual queremos deixar para os novos tempos e futuras gerações. Este artigo está longe de esgotar todas as possibilidades de interpretação e uso da fotografia no campo da educação ambiental crítica e, assim, torna-se um convite para aprofundarmos o diálogo, explorando, cada vez mais, a fotografia como linguagem e expressão, e considerando sua potência para o processo educativo, pesquisa e vivência para a transformação socioambiental. 


\section{Referências}

BANKS, M. Dados visuais para pesquisa qualitativa. Porto Alegre: Artmed, 2009.

BARTHES, R. A câmara clara: nota sobre a fotografia. Rio de Janeiro: Nova Fronteira, 1984.

BERGER, J. Modos de ver. Barcelona: Gustavo Gilli, 1974.

BORGES, M, D.; ARANHA, J. M.; SABINO, J. A fotografia de natureza como instrumento para a educação ambiental. Ciência \& Educação, Bauru, v. 16, n. 1, p. 149-161, 2010.

CARVALHO, I. C. M. Educação ambiental: a formação do sujeito ecológico. São Paulo: Cortez, 2008.

CARVALHO, I. C. M.; GRUM, M. Hermenêutica e educação. In: FERRARO JUNIOR, L. A. (Org.). Encontros e Caminhos: formação de educadoras(es) ambientais e coletivos educadores. Brasília: MMA, Diretoria de Educação Ambiental, 2005. p.175-188.

DRUMOND, M. A. et al. Estratégias para o uso sustentável da biodiversidade da Caatinga. In: SILVA, J. M. C.; TABARELLI, M.; FONSECA, M. T.; LINS, L. V. (Orgs.). Biodiversidade da Caatinga: áreas e ações prioritárias para a conservação. Brasília: MMA, 2004. p. 329-340.

FARNSWORTH, B. E. Conservation photography as environmental education: focus on the pedagogues. Environmental Education Research, s/1, v.17, n.6, p. 769-787, nov. 2011.

FERRARA, L. D'A. Olhar periférico: informação, linguagem, percepção ambiental. São Paulo: EDUSP, 1993.

FLICK, U. Introdução à pesquisa qualitativa. Porto Alegre: Artmed, 2009.

FREIRE, P. Pedagogia da autonomia. São Paulo: Paz e Terra, 2003.

GUIDO, L. F. E.; BRUZZO, C. O uso de imagens nas aulas de ciências naturais. Em Extensão, Uberlândia, v.7, p. 43-54. 2008.

GUIMARÃES, L. B.; PREVE, A. M. H. Fotografias de deslocamento no ambiente: fugas em uma prática educativa. In: IX ANPED-SUL. Seminário de Pesquisa em Educação da Região Sul, 2012, Caxias do Sul. ANAIS da IX ANPED-SUL. Caxias do Sul: UCS, 2012. v. 1. p. 1 12. http://www.portalanpedsul.com.br/admin/uploads/2012/Educacao_Ambiental/Trabalho/05_55 _11_410-7479-1-PB.pdf. Acesso > 04/03/2013.

GUIMARÃES, M. Educação Ambiental: no consenso um embate? Campinas: Papirus, 2000. 
HERMANN, N. Hermenêutica e educação. Rio de Janeiro: DP\&A, 2002.

HOEFFEL, J. L.; FADINI, A. A. B. Percepção ambiental. In: FERRARO JUNIOR, L.A. (Org.). Encontros e Caminhos: formação de educadoras(es) ambientais e coletivos educadores. Vol 2. Brasília: MMA, Diretoria de Educação Ambiental, 2007. p 253-262.

HOFSTATTER, L. J. V. O imagético de uma comunidade caatingueira e os sentidos atribuídos à onça em um processo formativo de educação ambiental crítica. 2013. 199f. Dissertação (Mestrado em Ecologia e Recursos Naturais) - Universidade Federal de São Carlos, São Carlos, 2013.

IARED, V, G.; DI TULLIO, A.; OLIVEIRA, H, T. Impressões de educadoras/es ambientais em relação a visitas guiadas em um zoológico. REMEA, Rio Grande. v. 28, p. 258-273. Jan./Jun. 2012.

INSTITUTO BRASILEIRO DE GEOGRAFIA E ESTATISTICA (IBGE). Censo Demográfico 2010. Disponível em http://www.ibge.gov.br/cidadesat/topwindow.htm?1. Acesso em: 2 nov. 2012.

JOLY, M. Introdução à análise da imagem. Campinas: Papirus, 2007.

LOIZOS, P. Vídeo, filme e fotografias como documentos de pesquisa. In: BAUER, W. M; GASKELL, G. (Orgs.). Pesquisa qualitativa com texto, imagem e som: um manual prático. Petrópolis: Vozes, 2010. p. 137-155.

MARIN, A. A.; OLIVEIRA, H. T.; COMAR, V. Percepción ambiental, imaginário y prácticas educativas. Tópicos en Educación Ambiental, Guadalajara, v.5, n.13, p.78-80, 2003.

MERLEAU-PONTY, M. Fenomenologia da percepção. 2 ed. São Paulo: Martins Fontes, 1999.

MICHELON, F. F. O mundo reconstruído em prata revelada: a discussão da fotografia como recurso e resultado do olhar investigativo. In: GALIAZZI, M.C.; FREITAS, J.V (Orgs.). Metodologias emergentes de pesquisa em educação ambiental. 2 ed. Ijuí: Unijuí, 2007.p. 179200.

MORAIS, F. M. R. Educação e fotografia. Contribuições à percepção de problemas ambientais. 2004. 309f. Dissertação (Mestrado em Recursos Florestais) - Universidade de São Paulo/Escola Superior de Agricultura Luiz de Queiroz, Piracicaba, 2004.

PENN, G. Análise semiótica de imagens paradas. In: BAUER, W.M.; GASKELL, G. (Orgs.). Pesquisa qualitativa com texto, imagem e som: um manual prático. Petrópolis: Vozes, 2010. P. 319-342.

OLIVEIRA, H. T. Transdisciplinaridade. In: FERRARO JUNIOR, L.A. (Org.). Encontros e Caminhos: formação de educadoras(es) ambientais e coletivos educadores. Brasília: MMA, Diretoria de Educação Ambiental, 2005. p. 333-342.

PIRES, J. B.; CONTANI, M. L. Imagem física e qualidade mental: a fotografia vista pela semiótica. Discursos fotográficos, Londrina, v.1, n.1, p.167-182, 2005. 
SALGADO, G. N. Educação ambiental e foto-dispositivo: outras imagens do Sertão de Peri. 2011. 131f. Dissertação (Mestrado em Educação) - Universidade Federal de Santa Catarina, Florianópolis, 2011.

SAMMEL, A. An invitation to Dialogue: Gadamer, Hermeneutic, Phenomenology, and Critical Environmental Education. Canadian Journal of Environmental Education, s/l, v.8, s/n, p. 155-168, Spring. 2003.

SANTAELLA, L. O que é semiótica. São Paulo: Brasiliense, 2007.

SANTAELLA, L. Leitura de imagens. São Paulo: Editora Melhoramentos, 2012.

SANTAELLA, L.; NOTH, W. Imagem: cognição, semiótica, mídia. São Paulo: Iluminuras, 2012.

SAUVÉ, L. Uma cartografia das correntes em educação ambiental. In: SATO, M.; CARVALHO.I. C. M. (Orgs). Educação ambiental: Pesquisa e desafios. Porto Alegre: Artmed, 2005a. p. 17-44.

SAUVÉ, L. Educação Ambiental: possibilidades e limitações. Educação e Pesquisa, São Paulo, v.31, n.2, p. 317-322, Mai./Ago. 2005b.

SILVEIRA, L. S; ALVEZ, J. V. O uso da fotografia na educação ambiental: tecendo considerações. Pesquisa em Educação Ambiental, Rio Claro, v.3, n. 2, p. 125-146, 2008.

SORRENTINO, M. De Tbilisi a Thessalonik: a educação ambiental no Brasil. In: QUINTAS, J. S. (Org.). Pensando e praticando a educação ambiental no Brasil. Brasília: IBAMA, 2002. p. 107-118.

SOUTO, F. J. B. A Imagem que fala. O uso da fotografia em trabalhos etnoecológicos. In: ALBUQUERQUE, U. P.; LUCENA, R. F. P.; CUNHA, L. V. F. C. (Orgs.). Métodos e técnicas na pesquisa etnobiológica e etnoecológica. Recife: NUPEEA, 2010, p. 173-185 (Série Estudos e Avanços, Vol. 1).

SOUSA SOBRINHO, J. Brejos da Barra-BA: Comunidades camponesas no processo de desenvolvimento no Vale do São Francisco. 2007. 271f. Dissertação (Mestrado em Geografia) - Universidade de São Paulo, São Paulo, 2006.

TACCA, F. Imagem fotográfica: aparelho, representação e significação. Psicologia $e$ Sociedade, Belo Horizonte,v.17, n.3, p.9-17, Set./Dez. 2005.

Versão recebida em 03/06/2015

Aceite em 19/08/2015 